\title{
Some aspects of the reproductive biology and sex-ratio of Cirrhina reba (Hamilton) (Cyprinidae : Cypriniformes)
}

\author{
Sarmin Akther and Shirin Akther \\ Department of Zoology, University of Rajshahi, Rajshahi 6205, Bangladesh
}

\begin{abstract}
Some aspects of the reproductive biology viz. sex-ratio gonadal length index (G.L.I.), gonado somatic index (G.S.I.) and sex-ratio of Cirrhina reba were studied during September 2004 to July 2005. In present study the highest values of GLI (33.76) and GSI (0.63) were in the month of July. Total length (TL) and gonadal length (GL), total weight (TW) and gonadal weight ( GW ), standard length (SL) and gonadal length ( $G L$ ) and gonadal weight relationships were found to be positive; and the relationships were: GL = $3.873+0.219 \mathrm{TL}(r=0.992), \mathrm{GW}=0.01511+0.000815 \mathrm{TL}(r=0.979), \mathrm{GL}=-2.6030+0.253 \mathrm{SL}(r=0.990)$, $\mathrm{GL}=0.01997+0.000938 \mathrm{SL}(\mathrm{r}=0.976), \mathrm{GW}=13.2952+0.6064 \mathrm{TW}(\mathrm{r}=0.958), \mathrm{GW}=0.0772+0.00233 \mathrm{TW}(\mathrm{r}$ $=0.979$ ). The sex- ratio of $C$. reba were $1: 1.62$ for male and female respectively. The Chi-square test showed significant differences of sex-ratio among months and totals.
\end{abstract}

Key words: Reproductive biology, sex- ratio of Cirrhina reba.

\section{Introduction}

The freshwater fish Cirrhina reba (Ham.) is locally known as "Raikhor", "Aikhor" or Bangla. Although the fish is rarely available in the eastern part of the country, but it is abundantly available in the western and north western part of Bangladesh (ADB, 1997). The fish in these areas are cultured in ponds along with the major carps like Labeo rohita, Catla catla, etc. Perhaps because of availability of its spawn in the rivers Padma and Jamuna. The species is generally recognized by its silvery yellowish colour, scales darkest at the upper and lower edges forming bluish bands above and 2 or 3 rows below the lateral line. Ventral side is white, but dorsal and caudal is grey or yellowish. Tip of the pelvic and anal fins are orange. Studies on the reproductive biology of fish are important for proper management of the fishery, stock assessment and evaluation of commercial potency. The breeding or spawning season repeats in cyclic orders in which the organism undergoes maturation change and there by gets ready to breed again. This repeated phenomenon are known as reproductive cycle or sexual periodicity (Afroze \& Hossain 1990), Hossain et al (1989, 1991), Parween et al (1993), Bhuiyan and Afrose (1996), Iqbal et al. (1996), Sultana et al (1998) and Karmakar et al (1999). The present investigations reveal that the breeding season (peak) of C. reba is April to July. The present study is aimed at providing a comprehensive account of the reproductive period and sex-ratio of $C$. reba in the freshwaters of Rajshahi based on reproductive system, sexual maturity, reproductive cycle etc.

\section{Materials and Methods}

A total of 1100 () specimens were collected for study from September 2004 to July 2005 (100 specimens in each month) from different fish landing centres of Rajshahi city. Among the total 1100 specimens collected, 673 were females and 427 males. Common experience was used identify the sex. After collection the specimens were preserved in $10 \%$ formalin solution. Gonads were dissected out and preserved in 5\% formalin solution in separate vials and plastic containers. During preservation the gonads were properly labelled for subsequent studies. Excess moisture was removed by blotting the surface of the fish as well as the gonads with blotting paper before taking weights. The gonadal lengths were taken with meter scale in $\mathrm{mm}$ and their weights in $\mathrm{g}$. To study reproductive cycle of $C$. reba two methods were applied. Gonadal length index (GLI) and Gonado somatic index (GSI) were calculated using the following formulas:

$$
\begin{aligned}
& \text { G.L.I } \frac{\text { Length ofthe gonad }}{\text { Total length of the fish }} \times 100 \\
& \text { G.S.I } \frac{\text { Weight of the gonad }}{\text { Weight of the fish }} \times 100
\end{aligned}
$$

Co-relations between the total length of fish and gonadal length and gonadal weight, and that between standard length of fish and gonadal length and gonadal weight were calculated. 


\section{Results and Discussion}

The breeding season of $C$. reba starts from April and continues up to October/November. Not only the weight of ovary increased with the appearance of the ripe ova but also the length of the ovary increased in relation to body length.

Gonadal Length Index (GLI): A total of 330 specimens were examined for GLI throughout the year. Higher values of GLI were obtained almost the year round except in the months of January to March. The peak shows that the month of JuneJuly is the peak breeding season. The highest (33.76) value of gonadal length index was observed during the month of July and the lowest (16.76) during January (Table 1). Afroze and Hossain (1990) recorded maximum and minimum value of GLI in Amblypharyngodon mola as $28.5 \pm$ 0.82 and $18.05 \pm 0.76$ respectively.

Gonado Somatic Index (GSI): The highest values of GSI of $C$. reba was observed in the month of July (0.63) while the lowest value (0.37) in the month of December (Table 1). The mature females bear mature and ripe ovaries which increase the value of GSI.

Table-01: Monthly variation in the mean values of gonadal length index and gonado somatic index of $C$. reba.

\begin{tabular}{clcc}
\hline Year & Month & $\begin{array}{c}\text { Mean values } \\
\text { of GLI }\end{array}$ & $\begin{array}{c}\text { Mean } \\
\text { values of } \\
\text { GSI }\end{array}$ \\
\hline \multirow{2}{*}{2004} & September & 26.89 & 0.46 \\
& October & 24.00 & 0.43 \\
& November & 23.68 & 0.41 \\
& December & 21.50 & 0.37 \\
& January & 16.76 & 0.44 \\
& February & 18.58 & 0.46 \\
& March & 20.21 & 0.48 \\
& April & 22.24 & 0.50 \\
& May & 25.24 & 0.57 \\
& June & 32.09 & 0.59 \\
& July & 33.76 & 0.63 \\
\hline
\end{tabular}

The regression equations between the total- and standard-length of the fish and length and weight of the gonad, were found to be linear and obtained as follows: $G L=-3.873+0.219 \mathrm{TL}(r=0.992)$ (Fig. $1), G W=0.01511+0.000815 \mathrm{TL}(r=0.979)(\mathrm{Fig}, 2)$, $\mathrm{GL}=-2.603+0.253 \mathrm{SL}(\mathrm{r}=0.990) \quad(\mathrm{Fig} .3), \mathrm{GW}=$
$0.01997+0.000938 \mathrm{SL}(r=0.976)$ (Fig. 4), $\mathrm{GL}=$ $13.2952+0.6064 \mathrm{TW}(r=0.958)$ (Fig. 5), GW = $0.0772+0.00233$ TW $(r=0.979)$ (Fig. 6).

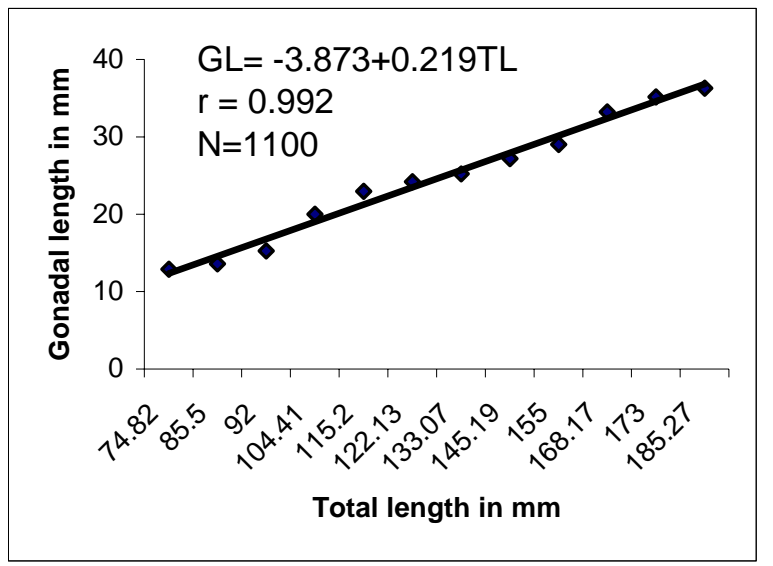

Fig. 1: Relation between total length $(T L)$ and gonadal length (GL) of $C$. reba.

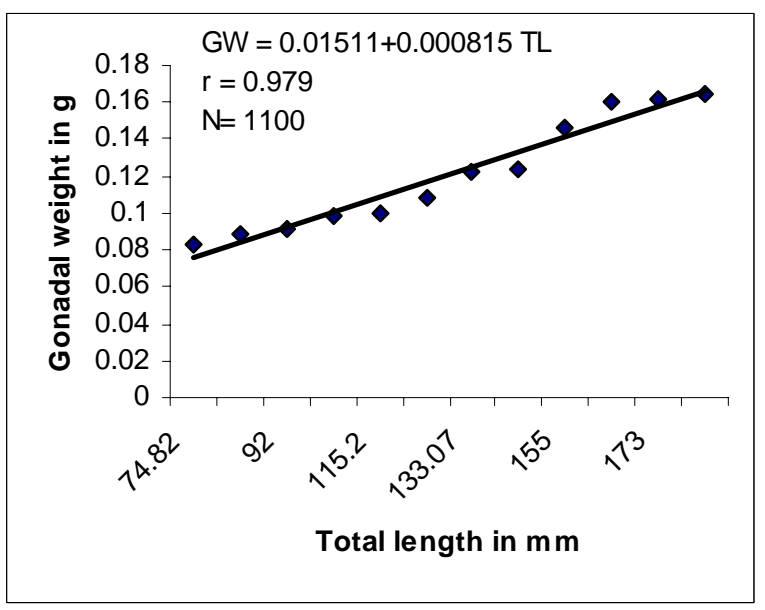

Fig. 2: Relation between total length $(T L)$ and gonadal weight (GW) of C. reba.

Sex ratio: Out of 1100 specimens of C. reba, 427 were males and 673 were females. The total male and female ratio was 1:1.62 (Table-2). This study revealed that the monthly fluctuation of male and female population occurs in the catch, and the percentage of female is higher than that of the male, throughout the year excepting the month of December. The chi-square showed significant difference among months and total male-female ratio of C. reba (Table 3). Shafi and Quddus (2004) recorded the sex-ratio of Mastacembelus pancalus as 50.27:49.73. 


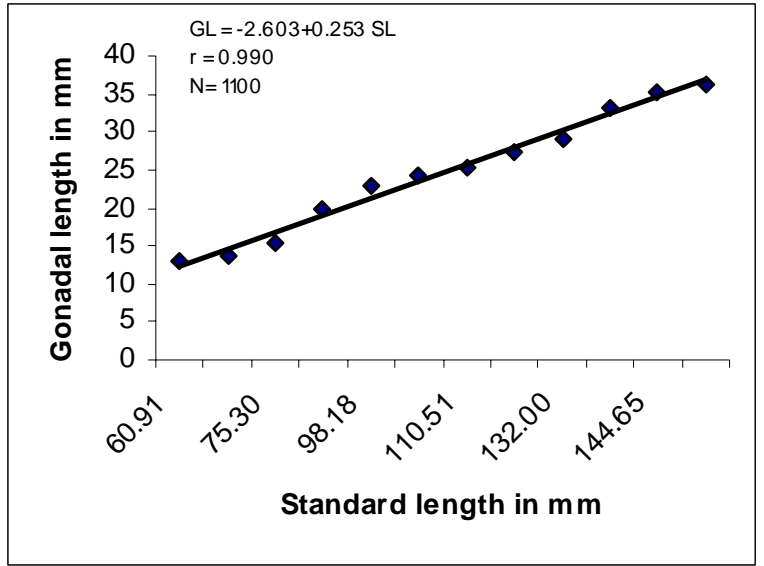

Fig. 3: Relation between standard length (SL) and gonadal length (GL) of C. reba.

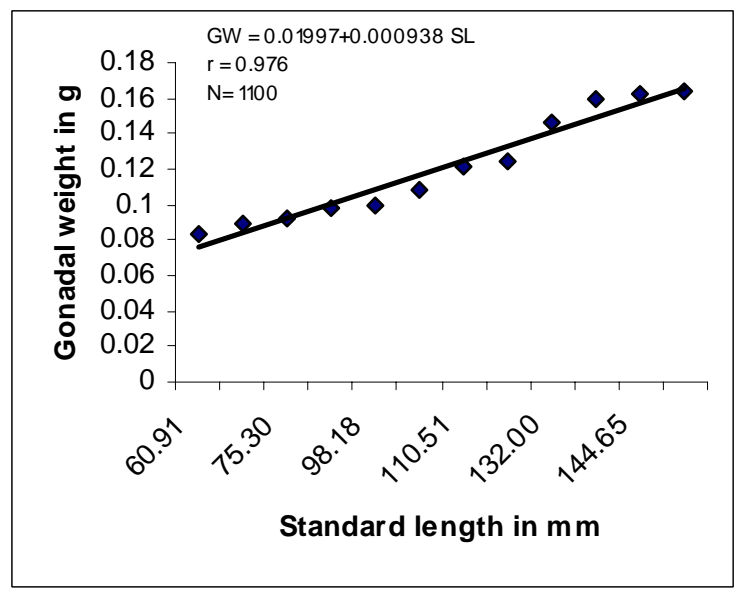

Fig. 4: Relation between standard length (SL) and gonadal weight (GW) of C. reba.

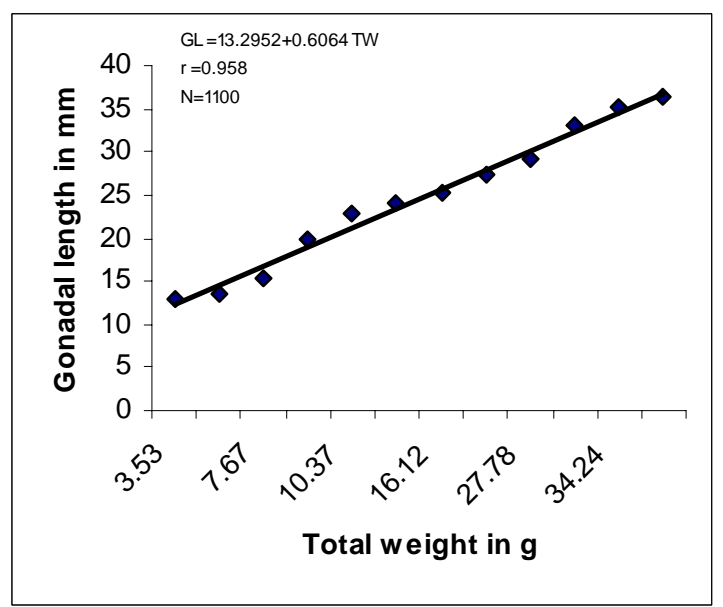

Fig. 5: Relation between total weight (TW) and gonadal length (GL) of C. reba.

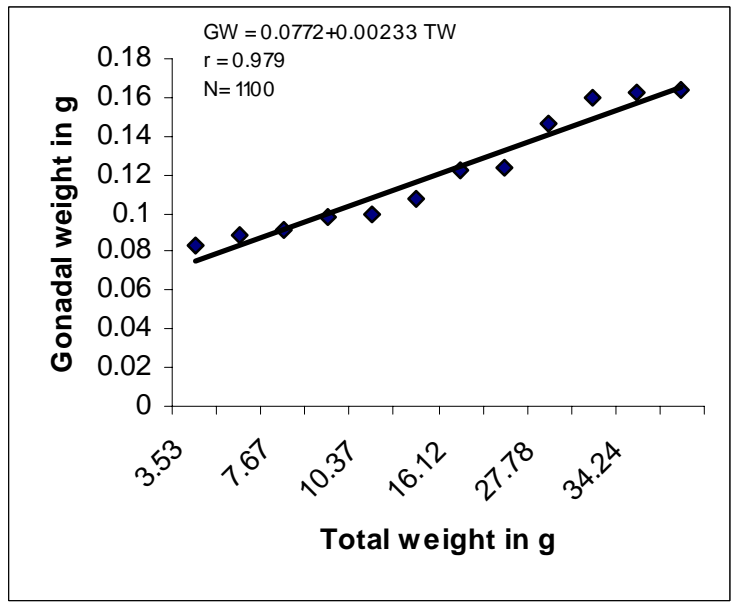

Fig. 6: Relation between total weight (TW) and gonadal weight $(\mathrm{GW})$ of $C$. reba.

Table-02. Month wise sex-ratio of $C$. reba.

\begin{tabular}{clcccc}
\hline Year & Month & $\begin{array}{c}\text { No of } \\
\text { fish }\end{array}$ & \multicolumn{2}{c}{ Male Female } & $\begin{array}{c}\text { Sex } \\
\text { ratio }\end{array}$ \\
\hline \multirow{3}{*}{2004} & September & 100 & 35 & 65 & $1: 1.86$ \\
& October & 100 & 39 & 61 & $1: 1.56$ \\
& November & 100 & 37 & 63 & $1: 1.70$ \\
& December & 100 & 51 & 49 & $1: 0.96$ \\
& January & 100 & 42 & 58 & $1: 1.38$ \\
& February & 100 & 43 & 57 & $1: 1.33$ \\
& March & 100 & 41 & 59 & $1: 1.44$ \\
2005 & April & 100 & 37 & 63 & $1: 1.70$ \\
& May & 100 & 36 & 64 & $1: 1.78$ \\
& June & 100 & 35 & 65 & $1: 1.86$ \\
& July & 100 & 31 & 69 & $1: 2.23$ \\
& Total & 1100 & 427 & 673 & $1: 1.62$ \\
\hline
\end{tabular}

Table- 3. The value of Chi-square $\left(\chi^{2}\right)$ test of $C$. reba.

\begin{tabular}{|c|c|c|c|c|c|}
\hline \multirow[b]{2}{*}{ Source } & \multicolumn{2}{|c|}{ Degree Observed } & \multicolumn{2}{|c|}{ Tabulated value } & \multirow[b]{2}{*}{ Probabilities } \\
\hline & $\begin{array}{c}\text { of } \\
\text { freedom }\end{array}$ & $\begin{array}{c}\text { value of } \\
\chi^{2}\end{array}$ & $5 \%$ & $1 \%$ & \\
\hline $\begin{array}{l}\text { Month } \\
\text { wise }\end{array}$ & 10 & 66.440 & 18.307 & 23.209 & Significant \\
\hline $\begin{array}{c}\text { Among } \\
\text { total }\end{array}$ & 1 & 55.014 & 3.841 & 6.635 & Significant \\
\hline
\end{tabular}

From the above findings it can be concluded that the breeding season of $C$. reba extends from April to October with the peak in June-July. Total length, standard length, total weight, gonadal length and gonadal weight relationship were found to be linear and positively correlated. The female were predominant almost through out the year.

\section{Acknowledgements}

The authresses would like to thank the Chairman, Department of Zoology, Rajshahi University, Rajshahi for providing necessary research facilities at the Department. 


\section{References}

ADB, 1997. North - West Area Development Study Project - Interim Report February, FISH ARISE. Vol - V. 2.

Afroze, S. \& Hossain, M.A 1990. The reproductive cycle of the freshwaterfish Amblypharyngodo mola (Hamilton) (Cypriniformers: Cyprinidae). Univ. J. zool. Rajshahi Univ. 9:17-21.

Bhuiyan, A.S. \& Afrose, R.1996. The fecundity and sexratio of Oreochromis nilotica (L) (Perciformes : Cichlidae). Univ. J. zool. Rajshahi Univ. 14: 29-32

Hossain, M.A., Taleb, A. \& Rahman, M. H. 1989. Reproductive and reproductive periodicity of Notopterus notopterus (Pall.) (Notopteridae: Clupeiformes). Bangladesh J. Aquaculture 11(2): 57-64.

Hossain, M.A., Rahman, M. H. \& Parween, S. 1991. A study on the sex-ratio and reproductive cycle of Nandus nandus (Hamilton - Buchanon) (Nandidae: Perciformes). J. Asiatic Soc. Bangladesh (Sci.), 17(2): 141-144.

Iqbal, S. M. ,Mortuza, M.G., Parween, S. and Hossain, $M$.A. 1996. Study on the reproductive and fecundity of Chanda ranga (Hamilton) and Chanda nama (Hamilton). Pakistan J. Zool. 28(4): 359-360.
Karmakar, B.R., Parween, S., Hossain, M.A. \& Mortuza, G.M. 1999. Some aspects of reproductive biology of Notopterus chitala (Hamilton) (Clupeiformes: Notopteridae). J. Bio-Sci. 7: 115-118

Lagler, K. F.1956. Fresh water Fishery Biology, $2^{\text {nd }}$ edition W.M.C. Brown Co. Dubuque. Pp. 106-110.

Parween, S., Begum, N., Rahman, M.H. \& Hossain, M.A. 1993. On the breeding periodicity of Esomus danricus (Hamilton). Univ. J. zool. Rajshahi Univ. 12: $31-34$.

Sultana, S., Parween,S., Hossain, M.A., \& Mortuza, M. A. 1998. Some aspects of reproductive biology of Pangasius pangasius (Ham.) Univ. J. zool. Rajshahi Univ. 17: 61-64.

Shafi, M. \& Quddas, M.M.A. 2004. Bangladesher Matsho Shompad. Kabir Publications, Dhaka, Bangladesh, Pp.440.

Yuen, H.S.H. 1955. Maturity and fecundity of big eye tuna in the Pacific. U.S. Fish and Wild Life Serv. Special. Sci. Rept. Fish. 150. 